\title{
A quick and simple method for the routine determination of acetyl- and butyrylcholinesterase in blood
}

\author{
M. BELLINO ${ }^{1}$, M. FICARRA ${ }^{2}$, N. FRONTALI ${ }^{1}$, F. GHEZZO ${ }^{2}, A . M$. GUARCINI $^{1}$, \\ F. ORECCHIO ${ }^{2}$, L. A. SERPIETRI ${ }^{1}$, AND M. E. TRAINA ${ }^{1}$
}

From the ${ }^{1}$ Istituto Superiore di Sanità, and the ${ }^{2}$ Istituto di Igiene, Università Cattolica, Rome, Italy

ABSTRACT The salient features of this method for biological monitoring of occupational exposure to organophosphorus insecticides are: (a) acetylcholinesterase (AChE) and butyrylcholinesterase $(\mathrm{BuChE})$ are determined separately in whole haemolysed blood using specific substrates at appropriate concentrations; (b) $20 \mu \mathrm{l}$ of blood drawn from the finger tip is sufficient for both determinations; (c) the blood sample is immediately diluted with a solution of saponin and may thereafter be frozen for storage; (d) diagnostic kits, commercially available for the determination of plasma BuChE, may be employed with modifications; (e) the kinetic procedure is avoided by blocking the enzyme reactions at the end of the incubation period. This paper describes attempts to achieve optimal conditions for the two reactions. Under the conditions finally chosen, the whole blood 'AChE' activity value still includes a small percentage of plasma BuChE activity $(12.5 \%$ of the total), while the whole blood 'BuChE' activity includes a small percentage of erythrocyte AChE activity ( $7 \%$ of the total). Results of determinations performed with this procedure on 172 healthy subjects are reported.

For the biological monitoring of those occupationally exposed to organophosphorus (OP) insecticides, determination of both erythrocyte acetylcholinesterase (AChE) (EC 3.1.1.7.) and plasma butyrylcholinesterase (BuChE) (EC 3.1.1.8.) is recommended (World Health Organization, 1973; Zavon, 1976). These assays sometimes must be performed routinely in small outlying laboratories. Methods are therefore called for which combine sensitivity and reliability with a minimal need for equipment. In large central laboratories, methods are preferred which lend themselves to automation and minimise the sources of error inherent in the preparation and shipment of the samples. Our new procedure meets these requirements and is based on the spectrophotometric method of Ellman et al. (1961), currently considered by most authors to be the method of choice. Erythrocytes and plasma preferably should be separated before transport (Zavon, 1976) but this constitutes a considerable source of error, besides being time-consuming. This inconvenience is overcome in our method by performing both tests on whole blood. Another

Received for publication 10 June 1977 Accepted for publication 3 July 1977 potential disadvantage is the unknown amount of haemolysis during preparation and transport of the sample. We have therefore chosen to haemolyse completely the blood immediately after sampling, as already proposed by Winteringham and Disney (1964) for their radiometric method. The sample may then be frozen for storage and transport.

A series of experiments has been performed (a) in order to optimise the conditions for the separate determination of $\mathrm{AChE}$ and of $\mathrm{BuChE}$ on samples of whole haemolysed blood (this is performed with specific substrates at appropriate concentrations and does not involve the use of inhibitors); (b) in order to block the reactions at the end of the incubation period, thus avoiding the kinetic procedure.

\section{Materials and methods}

Samples of heparinised blood (1-2 ml) from healthy subjects were diluted $(1: 10 \mathrm{v} / \mathrm{v})$ with a solution of saponin (Merck) $(1.0 \mathrm{~g} / 1$ in $51 \mathrm{mM} \mathrm{NaCl})$ and, if not used immediately for experiments, stored at $-20^{\circ} \mathrm{C}$. In other cases plasma and erythrocytes were separated by centrifugation and repeated washing of the erythrocytes with $154 \mathrm{mM} \mathrm{NaCl}$ before dilution and freezing. 
For cholinesterase determination acetyl thiocholine iodide (ATCh) and butyrylthiocholine iodide (BuTCh) at different concentrations were used as substrates, and the reagents (matching those of commercial kits such as that marketed by Biochemia) were $0.25 \mathrm{M} \quad 5,5^{\prime}$-dithiobis-(2-nitrobenzoic acid) (DTNB) in $0.05 \mathrm{M}$ phosphate buffer, $\mathrm{pH} 7.2$ (with ATCh as substrate) or $\mathrm{pH} 7 \cdot 7$ (with BuTCh as substrate).

The experiments for perfecting the procedure involved the kinetic method of Ellman et al. (1961), with the temperature of the cuvette holder of the spectrophotometer (Beckman DU) regulated at $25^{\circ}$.

Three-millilitre aliquots of reagent were initially incubated at the same temperature after addition of the enzyme preparation. Readings were taken at $405 \mathrm{~nm}$ at different time intervals after the addition of the substrate, against a blank comprising the same components without substrate. Spontaneous hydrolysis was estimated by means of a similar set of tubes lacking the enzyme preparation.

Other compounds used were eserine salicylate (Merck) and sodium dodecylsulphate (SDS) (Serva).

\section{PRELIMINARY EXPERIMENTS}

Optimal enzyme concentration and incubation time Whole blood, diluted as described, was added to the

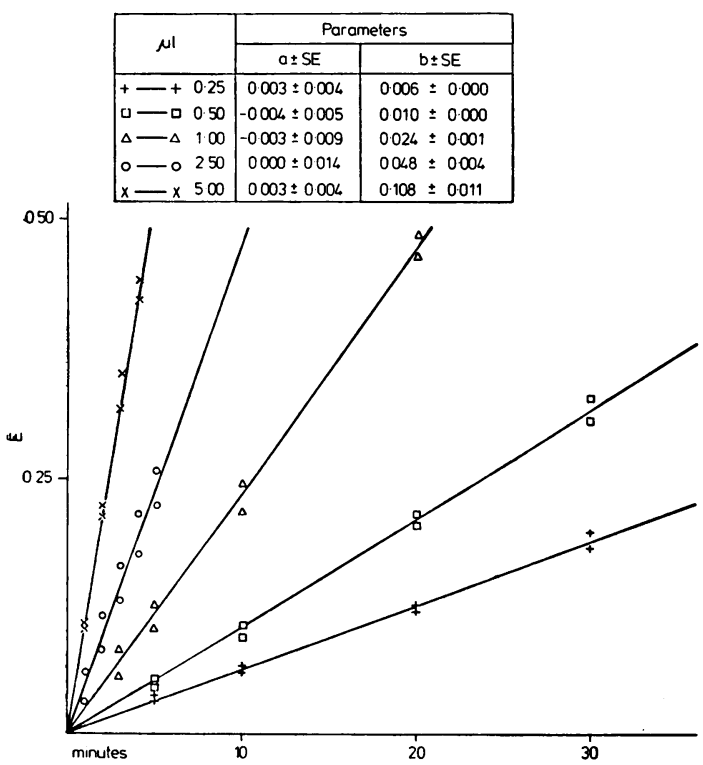

Fig. 1 Hydrolysis of 1.0 mM ATCh (as a function of time) by various concentrations of whole blood $(\mu \mathrm{l} / 3 \mathrm{ml}$ reagent), and interpolated regression lines. $E=$ extinction at $405 \mathrm{~nm}$.

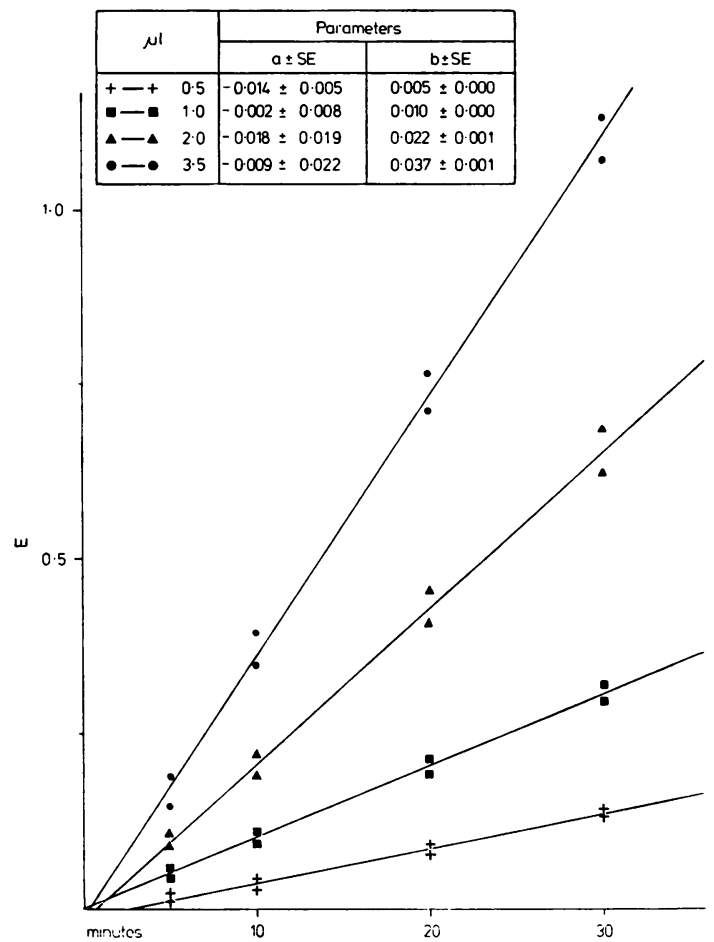

Fig. 2 Hydrolysis of $2.0 \mathrm{mM}$ BuTCh (as a function of time) by various concentrations of whole blood $(\mu \mathrm{l} / 3 \mathrm{ml}$ reagent $)$, and interpolated regression lines. $E=$ extinction at $405 \mathrm{~nm}$.

reagent in different amounts, corresponding to $0 \cdot 25-5 \cdot 0 \mu \mathrm{l}$ of whole blood. The subsequent incubation used $1.0 \mathrm{mM}$ ATCh and $2.0 \mathrm{mM}$ BuTCh as substrates. Figures 1 and 2 show the results expressed as extinction (E) as a function of time, after subtraction of spontaneous hydrolysis $(E / m i n$ values for spontaneous hydrolysis were 0.0010 for ATCh and 0.0012 for $\mathrm{BuTCh})$. The interpolated regression lines are also shown. Figure 1 does not report data for extinction values above 0.5 , but with up to $1.0 \mu \mathrm{l}$ blood the reaction was linear for at least 45 minutes.

Figures 3 and 4 show the difference in extinction/ minute $(\mathrm{E} / \mathrm{min})$ as a function of enzyme concentration. As long as the estimated ' $a$ ' values did not differ significantly from zero, the $\mathrm{E} / \mathrm{min}$ values were evaluated according to the calculated ' $b$ ' parameters of the interpolated regression lines in Figs. 1 and 2 . The analysis of variance for the linear interpolation was highly significant in both cases; the relevant numbers are shown in the Figures.

On the basis of the data reported in this section, we have chosen as standard conditions a time interval of 15 minutes and enzyme concentrations 


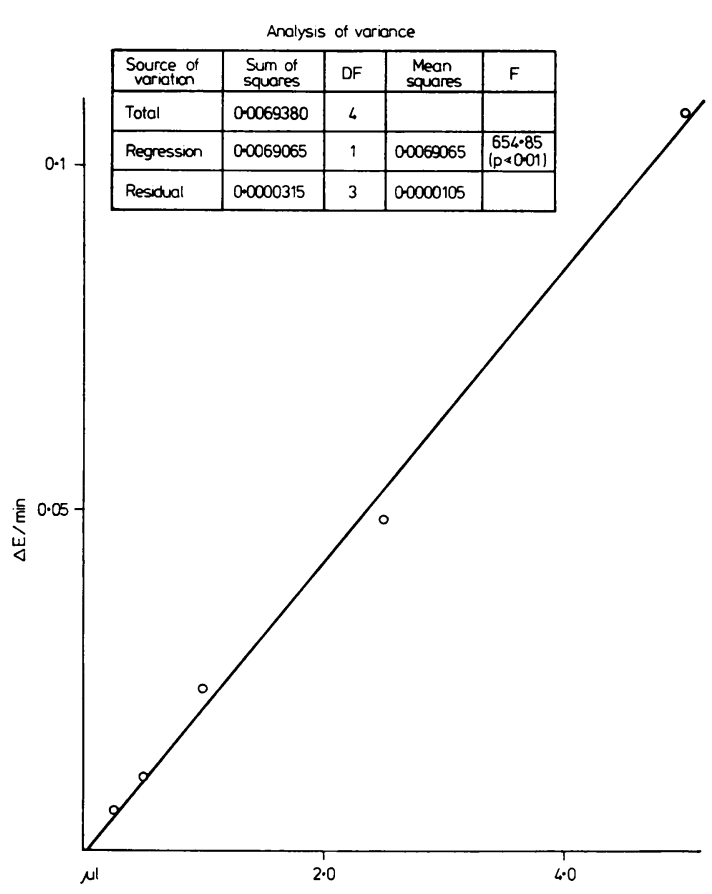

Fig. 3 Hydrolytic activity as a function of whole blood concentration ( $\mu \mathrm{l} / 3 \mathrm{ml}$ reagent), using $1.0 \mathrm{mM}$ ATCh as substrate. Activity is expressed as difference in extinction/minute.

corresponding to $1.0 \mu \mathrm{l}$ of whole blood $/ 3 \mathrm{ml}$ of reagent when ATCh is used as a substrate, or $2.0 \mu \mathrm{l} / 3$ $\mathrm{ml}$ when BuTCh is used.

\section{Optimal substrate concentrations}

Enzyme activity was determined as a function of substrate concentration. Experiments were performed with blood samples from different subjects. Figures 5 and 6 are examples of the results which were constantly obtained with ATCh and BuTCh respectively as substrates. It is well known (Silver, 1974) that the curves obtained under these conditions are bell-shaped (parabolic) for AChE from various sources, including mammalian erythrocytes, while for plasma BuChE they are S-shaped (sigmoid). When whole blood was incubated with ATCh in our experimental conditions, the activity/ substrate concentration curve was bell-shaped. With this substrate the activity of whole blood AChE obviously is preferentially determined, compared with the activity of BuChE. The activity attributable to the plasma enzyme (lower curve in Fig. 5) is characteristically S-shaped, and accounts for only a small percentage of the whole blood

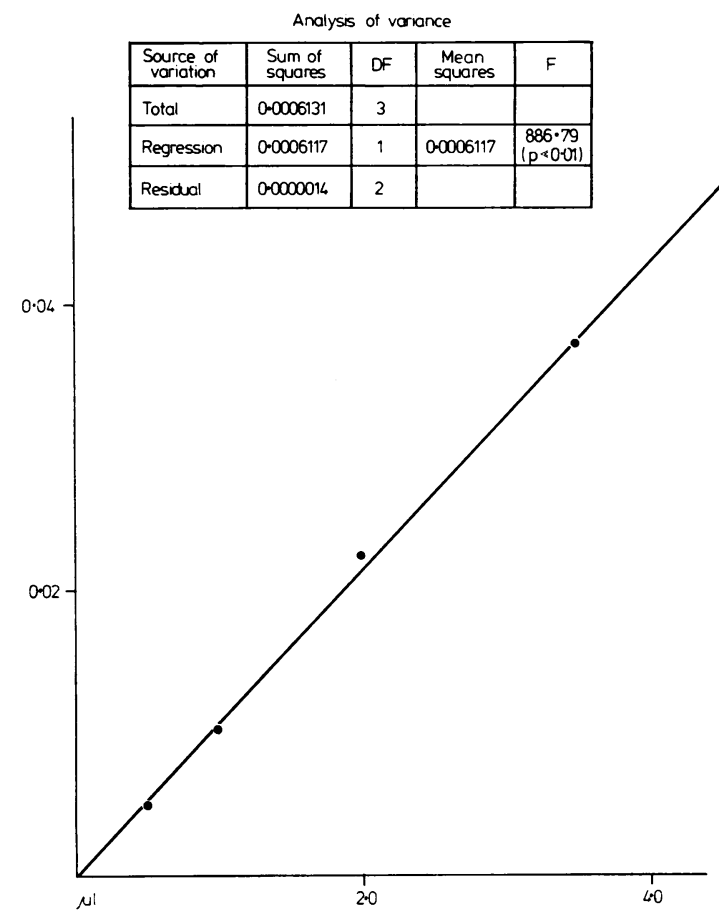

Fig. 4 Hydrolytic activity as a function of whole blood concentration ( $\mu \mathrm{l} / 3 \mathrm{ml}$ reagent), using $2.0 \mathrm{mM}$ BuTCh as substrate. Activity is expressed as in Fig. 3.

hydrolytic activity. This percentage is approximately $12.5 \%$ with $0.5 \mathrm{mM}$ ATCh. For the purpose of the procedure presented in this paper we will neglect this small percentage of $\mathrm{BuChE}$, and the term 'AChE' will be used to designate the hydrolytic activity of whole blood tested under the conditions mentioned, which are taken as standard.

When whole blood was incubated with BuTCh under our experimental conditions, the activity/ substrate concentration curve was S-shaped (Fig. 6). With this substrate BuChE activity is preferentially determined, rather than AChE. The activity attributable to the erythrocytes (washed preparation) accounts for only a small percentage of the whole blood hydrolytic activity. This percentage is around $7 \%$ with $2.0 \mathrm{mM} \mathrm{BuTCh}$. Once again, for the purpose of the procedure devised in the experiments described here, we will neglect this small percentage of AChE activity and will use the term ' $\mathrm{BuChE}$ ' to designate the hydrolytic activity of whole blood tested under the conditions discussed.

Inhibition of the enzyme reactions A way of inhibiting the enzyme reactions was 


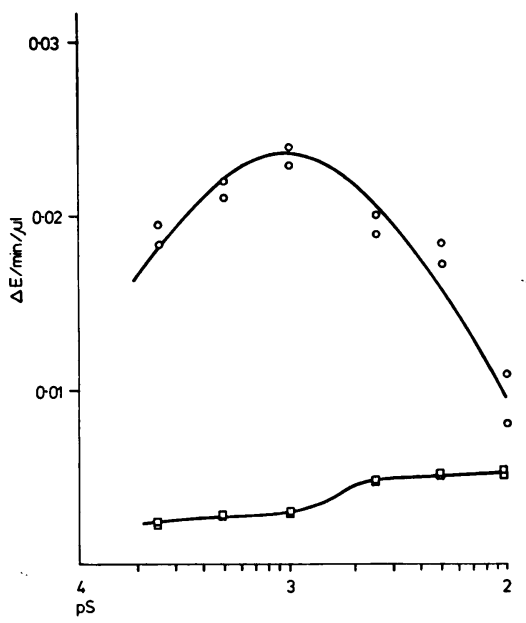

Fig. 5 Hydrolytic activity of whole blood $(\bigcirc)$ and of plasma ( $\square$ ) as a function of ATCh concentration ( $p S=$ negative logarithm of mol/litre). Activity is expressed as difference in extinction/minute/ul of whole blood.

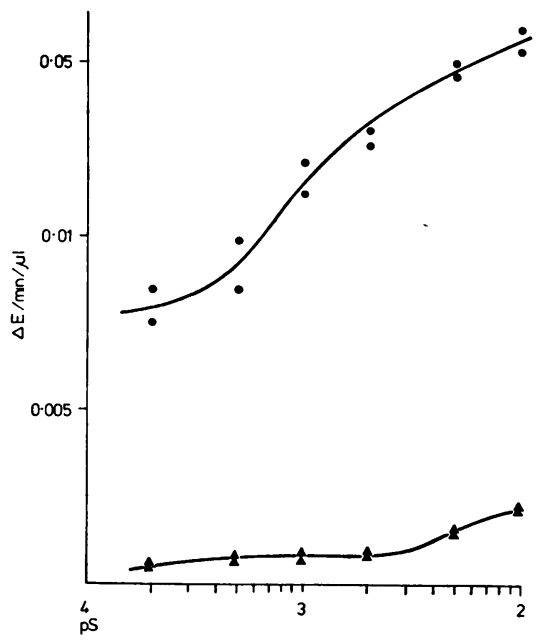

Fig. 6 Hydrolytic activity of whole blood (O) and of erythrocytes $(\mathbf{\Delta})$ as a function of BuTCh concentration. Activity and substrate concentration are expressed as in Fig. 5.

sought in order to avoid the time-consuming kinetic method.

Eserine Figure 7 shows the effects of the addition of various concentrations of eserine on the enzyme reactions taking place under the conditions chosen as described above, namely, for 'AChE', $1 \mu 1$ of whole blood $/ 3 \mathrm{ml}$ reagent and $0.5 \mathrm{mM}$ ATCh as substrate; for 'BuChE' $2 \mu \mathrm{l}$ of whole blood $/ 3 \mathrm{ml}$ reagent and $2.0 \mathrm{mM}$ BuTCh as substrate (at $25^{\circ} \mathrm{C}$ as usual). While 'AChE' is $100 \%$ inhibited by $0.01 \mathrm{mM}$ eserine, 'BuChE' is $100 \%$ inhibited by $0.3 \mathrm{mM}$ but not completely inhibited by $0.1 \mathrm{mM}$ eserine.

Sodium dodecylsulphate Figure 8 shows the effect of the addition of two different concentrations of SDS under the same experimental conditions as above. When the final concentration of SDS was $7.0 \mathrm{mM}$ the activity of both 'AChE' and BuChE' was immediately and totally inhibited, while $2.8 \mathrm{mM}$ SDS sufficed for the total inhibition of the activity of 'AChE' but not of 'BuChE'.

In order to stop each of the two reactions at the end of the incubation period, we employed final concentrations of either $0.3 \mathrm{mM}$ eserine or of $7.0 \mathrm{mM}$ SDS.

\section{NEW PROCEDURE}

On the basis of the preceding experiments the following procedure was established. Instructions are included for the adaptation of commercial kits, which are currently available for the determination of plasma cholinesterase, employing either ATCh or BuTCh as substrates. Some laboratories may prefer them because of their convenience, in spite of the higher cost.

For haemolysis, a saponin solution of $1.0 \mathrm{~g} / 1$ in $51 \mathrm{mM} \mathrm{NaCl}$ is used. The reagent is $0.25 \mathrm{mM}$ DTNB in $0.5 \mathrm{mM}$ phosphate buffer $\mathrm{pH} \mathbf{7 . 2}$ (for AChE) or $7 \cdot 7$ (for BuChE); this is the unmodified solution 1 of the commercial kits. The substrates are $156 \mathrm{mM}$ ATCh (solution 2 of the corresponding commercial kit); $310 \mathrm{mM}$ BuTCh (solution 2 of the corresponding commercial kit, but dissolved in $2.1 \mathrm{ml}$ instead of in $3.0 \mathrm{ml}$ ). The solution to stop the reaction is 0.433 M SDS $(125 \mathrm{~g} / \mathrm{l})$ or $18.2 \mathrm{mM}$ eserine salicylate $(7.5$ $\mathrm{mg} / \mathrm{ml})$.

A $20 \mu 1$ sample of blood is drawn up with a clean dry pipette from a pricked finger tip and immediately mixed with $1.0 \mathrm{ml}$ of the haemolysing solution (dilution 1:51). After one hour (to allow for complete clearing) the solution may be frozen for storage. Before the assay the haemolysates are thawed and thoroughly shaken in order to ensure homogenisation.

\section{Determination of ' $A C h E$ '}

For each haemolysate a set of three test tubes, each containing $3 \mathrm{ml}$ of DTNB reagent, is placed in a water bath at $25^{\circ} \mathrm{C}$ (other temperatures may be used if more convenient). Three $50 \mu \mathrm{l}$ aliquots of the same haemolysate are added to each set of test tubes, and this procedure is repeated for each haemolysate. An additional set of three test tubes, each containing $3 \mathrm{ml}$ of reagent, is incubated without the addition 

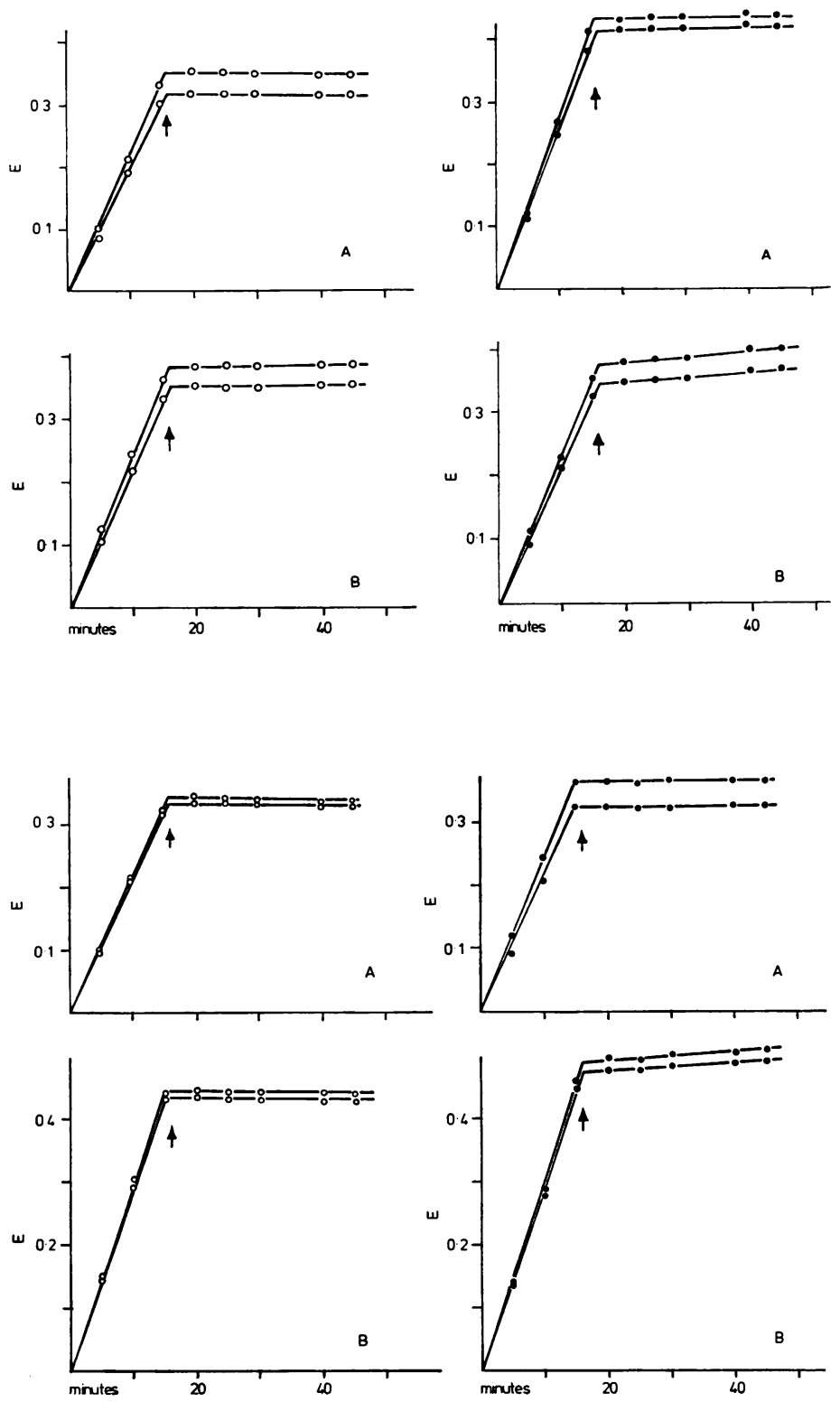

Fig. 7 The activity of whole blood 'AChE' (O) is immediately and completely inhibited by the addition (arrow) of $0.1(A)$ and $0.01 \mathrm{mM}$ eserine $(B)$. The activity of whole blood 'BuChE' (O) is inhibited slightly less than $100 \%$ by $0.1 \mathrm{mM}$ eserine $(B)$ and $100 \%$ by $0.3 \mathrm{mM}$ eserine $(A)$. $E=$ extinction at $405 \mathrm{~nm}$; conditions as described in text.
Fig. 8 The activity of whole blood ' $A C h E$ ' $(\bigcirc)$ is immediately and completely blocked by the addition (arrow) of 7.0 (A) and $2 \cdot 8 \mathrm{mM} S D S(B)$. The activity of 'BuChE' (O) is $100 \%$ inhibited by $7.0 \mathrm{mM} S \mathrm{SS}(A)$, but slightly less than $100 \%$ by $2.8 \mathrm{mM} S D S(B)$. $E=$ extinction at $405 \mathrm{~nm}$; conditions as described in text. of haemolysate, in order to determine the spontaneous hydrolysis of the substrate. At 0 time $10 \mu$ l of the ATCh solution is added to test tubes 2 and 3 of each set (including the set for spontaneous hydrolysis), while test tube 1 of each set is kept as a blank. The time taken for the addition of the substrate to the whole set of test tubes is recorded. After exactly 15 minutes' incubation, $50 \mu 1$ of the inhibitory solution is added to each test tube, taking care to proceed at the same speed as for the addition of the substrate. Each addition is followed by thorough shaking. The test tubes are removed from the water bath and test tubes 2 and 3 of each set are read against test tube 1 on a photometer at $405 \mathrm{~nm}$. Values for spontaneous hydrolysis are subtracted. The difference is a measure of enzyme activity 

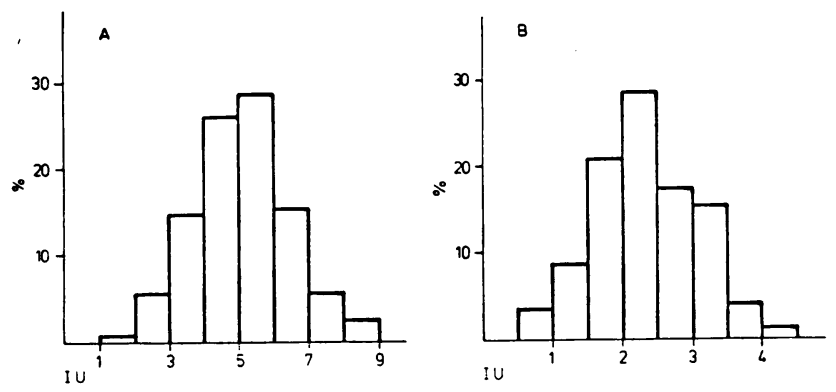

Fig. 9 Histograms representing the percentage frequency distribution of whole blood 'AChE' $(A)$ and 'BuChE' $(B)$ activity (IU) in healthy subjects.

expressed as extinction/15 minutes. Multiplication by the factor 15.550 converts this into International Units $(\mathrm{IU}) / \mathrm{ml}$, i.e. $\mu \mathrm{M}$ of substrate hydrolysed in one minute by one $\mathrm{ml}$ of whole blood.

\section{Determination of ' $\mathrm{BuChE}$ '}

The procedure is the same as for $\mathrm{AChE}$, with the difference that $100 \mu \mathrm{l}$ of haemolysate and $20 \mu \mathrm{l}$ of substrate (BuTCh) are employed. The values expressed as extinction/15 minutes are converted into $\mathrm{IU} / \mathrm{ml}$ by multiplying by the factor 7.925.

\section{DETERMINATION OF NORMAL LEVELS}

Blood was taken from healthy subjects (men aged 20-25 years and women aged 18-49 years) during routine medical visits before employment. The results are shown in Table 1 . The differences between men and women in 'AChE' and 'BuChE' values were not statistically significant. Table 2 shows the pooled data with the confidence limits. The distribution of the pooled data is shown by the histograms in Fig. 9.

Table 1 Enzyme activity in healthy men and women

\begin{tabular}{llcll}
\hline Enzyme & $\begin{array}{l}\text { Subjects } \\
\text { Sex }\end{array}$ & Number & $\begin{array}{l}\text { Mean enzyme activity } \\
(\text { IU/ml whole blood })\end{array}$ & $P^{*}$ \\
\hline 'AChE' & Female & 71 & $5 \cdot 175( \pm 0.179) \dagger$ & \\
& Male & 72 & $4.986( \pm 0.138)$ & $>0.4$ \\
'BuChE' & Female & 71 & $2.462( \pm 0.094)$ & $>0.05$ \\
& Male & 101 & $2.260( \pm 0.044)$ & $>0.04$ \\
\hline
\end{tabular}

*Significance of the difference between means (Student's $t$ test). †SE in parentheses.

Table 2 Enzyme activity; pooled data for both sexes

\begin{tabular}{llll}
\hline Enzyme & No. of subjects & $\begin{array}{l}\text { Mean enzyme activity } \\
(\text { IUlml whole blood })\end{array}$ & $\begin{array}{l}\text { Confidence } \\
\text { limits }(0.95)\end{array}$ \\
\hline 'AChE' & 143 & $5.079( \pm 0.109)^{*}$ & $2.437-7.721$ \\
'BuChE' & 172 & $2.343( \pm 0.054)$ & $1.023-3.854$ \\
\hline
\end{tabular}

*SE in parentheses.

\section{Discussion}

The thiocholine/DTNB colorimetric method, originally proposed by Ellman et al. (1961) for the determination of erythrocyte and tissue AChE, has been modified by several authors for the determination of plasma cholinesterase (Weber, 1966; Voss and Schuler, 1967; Wilhelm, 1968; Szasz, 1968). Others have adapted the method for the routine determination of erythrocyte AChE (Sirchia et al., 1970) or of both the plasma and the erythrocyte enzymes (Humiston and Wright, 1967; Voss and Sachsse, 1970). All of these methods entail the separation of plasma from erythrocytes by centrifugation, a step which, besides being time-consuming, is also a considerable source of error. The procedure proposed in this paper avoids this step and provides a measure of the activity of the two enzymes in whole blood through the use of specific substrates at appropriate concentrations. The whole blood 'AChE' activity value includes also a small percentage of plasma BuChE activity accounting for $12.5 \%$ of the total; the whole blood 'BuChE' activity includes also a small percentage of erythrocyte AChE activity accounting for $7 \%$ of the total. For the biological monitoring of large numbers of people exposed to organophosphorus compounds this drawback may be acceptable in view of the considerable increase in convenience and speed. Easy adaptability of diagnostic kits and avoidance of the kinetic method by blocking the enzyme reactions, are other advantages of the proposed procedure, which also lends itself to automation.

\section{References}

Ellman, G. L., Courtney, K. D., Andres, V. Jr., and Featherstone, R. M. (1961). A new and rapid colorimetric determination of acetylcholinesterase activity. Biochemical Pharmacology, 7, 88-95.

Humiston, C. G., and Wright, G. J. (1967). An automated method for the determination of cholinesterase activity. Toxicology and Applied Pharmacology, 10, 467-480.

Silver, A. (1974). In The Biology of Cholinesterases, 1st 
edition, pp. 32-37. North Holland Publishing Co.: Amsterdam and Oxford.

Sirchia, G., Ferrone, S., and Zanella, A. (1970). Determination of red cell acetylcholinesterase activity by diagnostic kit; modification of the method. Acta Vitaminologica et Enzymologica, 24, 219-221.

Szasz, G. (1968). Cholinesterase Bestimmung in Serum mit Acetyl und Butyrylthiocholin als Substrat. Clinica Chimica Acta, 19, 191-203.

Voss, G., and Sachsse, K. R. (1970). Red cell and plasma cholinesterase activities in microsamples of human and animal blood determined simultaneously by a modified acetylcholine/DTNB procedure. Toxicology and Applied Pharmacology, 16, 764-772.

Voss, G., and Schuler, J. (1967). A fast and simple procedure for routine determination of plasma cholinesterase activities. Bulletin of Environmental Contamination and Toxicology, 2, 357-363.
Weber, H. (1966). Rasche und einfache Ultramikromethode zur Bestimmung der Serumcholinesterase. Deutsche Medizinische Wochenschrift, 91, 1927-1932.

Wilhelm, K. (1968). Determination of human plasma cholinesterase activity by adapted Ellman's method. Arhiv za Higijenu Rada i Toksikologiju, 19, 199-206.

Winteringham, F. P. W., and Disney, R. W. (1964). A radiometric study of cholinesterase and its inhibition. Biochemical Journal, 91, 506-514.

World Health Organization (1973). XX Rapport du Comité d'Experts des Insecticides. Securité d'Emploi des Pesticides. Technical Report No. 513. WHO: Geneva.

Zavon, M. R. (1976). Biological monitoring in exposure to cholinesterase inhibitors. Workshop of Subcommittee on Pesticides of the Permanent Commission and International Association on Occupational Health.International Archives of Occupational and Environmental Health, 37, 65-71.

\section{The February 1978 issue}

\section{THE FEBRUARY 1978 ISSUE CONTAINS THE FOLLOWING PAPERS}

In vivo observations of skin capillaries in workers exposed to vinyl chloride. An English-American comparison H. R. MARICQ, C. S. DARKE, R. MCL. ARCHIBALD, AND E. C. LEROY

Arsenic exposure and mortality: a case-referent study from a Swedish copper smelter O. AXELSON, E. DAHLGREN, C.-D. JANSSON, AND S. O. REHNLUND

Respiratory function and symptoms in workers exposed simultaneously to jute and hemp $\mathbf{S}$. $\mathbf{H}$. EL GHAWABI

Determination of plasma lead levels in normal subjects and in lead-exposed workers A. CAVALLERI, C. MINOIA, L. POZZOLI, AND A. BARUFFINI

A seven-year review of measured hearing levels in male manual steelworkers with high initial thresholds R. W. HOWELL

Interaction between silica and hydrophobic cations J. DEPASSE

Trichloroethylene exposure. Biological monitoring by breath and urine analyses P. O. DROZ AND J. G. FERNÁNDEZ

Differences following skin or inhalation exposure in the absorption and excretion kinetics of trichloroethylene and toluene AKIO SATO AND TAMIE NAKAJIMA
Absorption of $m$-xylene vapours through the respiratory tract and excretion of m-methylhippuric acid in urine $w$. SEŃCZUK AND J. ORŁOWSKI

Simultaneous determination by gas chromatography of the major metabolites in urine of toluene, xylenes and styrene P. B. VAN ROOSMALEN AND I. DRUMMOND

A simplified method for rapid determination of porphyrins by thin-layer chromatography $T$. OKUDA, H. NAKAJIMA, K. YATSUKI, M. AMANO, AND G. UMEDA

A new method of carboxyhaemoglobin determination J. H. SANDERSON, M. F. SOTHERAN, AND J. P. STATTERSFIELD

Determination of urinary manganese by the direct chelation-extraction method and flameless atomic absorption spectrophotometry T. WATANABE, R. TOKUNAGA, T. IWAHANA, M. TATI, AND M. IKEDA

Book reviews

Notices

Information section

Copies are still available and may be obtained from the PUBLISHING MANAGER, BRITISH MEDICAL ASSOCIATION, TAVISTOCK SQUARE, LONDON, wC1H 9JR, price $£ 3.75$ (USA \$9.20), including postage 